\title{
SCREENING THE SPECIFIC SUBSTRATES OF ADENYLATION DOMAIN FROM MARINE ACTINOMYCETES BY FLUORESCENCE QUENCHING AND ISOTHERMAL TITRATION CALORIMETRY
}

\author{
MING LEI ${ }^{1 *}$, ZHIJUAN ZHAO ${ }^{\prime \sharp}$, KE LIU', YANLI LIU', HUI ZHANG', \\ XUE WU', SIYING GONG', YANLING MA², HAOBIN ZHAO', JINLIN LIU', \\ JINRONG MIN ${ }^{1}$ and CHAO QI'* \\ ${ }^{1}$ College of Life Science, Central China Normal University, Wuhan, China \\ ${ }^{2}$ College of Food and Horticultural Sciences, Foshan University, Foshan, China
}

\begin{abstract}
Adenylation domain (A domain) is a model of non-ribosomal peptide synthetases (NRPs), responsible for binding and activating the substrates-amino acids. In this study, a pGEX-2T-sare0718 recombinant plasmid (the gene sare0718 was cloned from Salinispora arenicola CNS-205, S. arenicola CNS-205) was transformed and expressed as a protein GST-Sare0718. Fluorescence quenching (FQ) was conducted to investigate the binding of 20 common amino acids to GST-Sare0718, then isothermal titration calorimetry (ITC) also be used. The results of FQ revealed that intrinsic fluorescence of GST-Sare 0718 is quenched steadily by addition of aspartic acid (Asp) and glutamine (Gln) through static quenching mechanism. The binding constants $\mathrm{K}_{\mathrm{a}}$ are Asp $\left(1.504 \times 10^{6} \mathrm{~L} / \mathrm{mol}\right)=\mathrm{Gln}\left(1.468 \times 10^{5} \mathrm{~L} / \mathrm{mol}\right)$. And there is one binding site on the protein GST-Sare 0718 . We confirmed Asp preference of GST-Sare 0718 by ITC. Therefore, Asp is the specific substrate. In addition, the experimental data indicates that the prediction system, "the specificity-conferring code", is not suitable for marine actinomycetes. So it is urgent to set up a special predictive system for marine actinomycetes.
\end{abstract}

Keywords: a domain, aspartic acid, fluorescence quenching (FQ), isothermal titration calorimetry (ITC), marine actinomycetes, static quenching

In recent years, actinomycetes play a profound role in the development of natural pharmaceutical products, such as polyketides (PKs) and NRPs (1). Marine actinomycetes, which are with heavy salinity, high pressure, low oxygen, and short nutrient, have been isolated from the marine environment (sediments, sponges, etc.) (2, 3). Marine actinomycetes are unparalleled source of new medicine and bioactive substance with unique medicinal value (4). In 2005, Fenical's group identified "Salinispora" as the first marine specificity actinomycete. $S$. arenicola CNS-205, a representative strain of "Salinispora", was isolated from deep-sea sediments of Palau. Bioinformatics analysis indicated that approximate $10.9 \%$ of the genome in S. arenicola CNS-205 is used for assembling natural products. Many scientists developed it as a new important resource of natural medicine (5).

A domain is the core of each module, responsible for recognizing the cognate amino acid and activating it as an aminoacyl adenylate as shown in Figure 1 (6). ATP- $\left[{ }^{32} \mathrm{P}\right]$ pyrophosphate (PPi) exchan- ge assay is a traditional method for analyzing A domain activity. However, it is not conducive to screening low-affinity substrates. And many laboratories don't have the ability to get high-throughput radioactive materials. FQ and ITC are usually used to study molecular interactions with some advantages, for example, non-radioactive, simple and convenient, etc.

In this study, FQ and ITC were used to screening the specific substrate of GST-Sare0718. This work can set up the foundation of exploring unknown NRPSs-related gene cluster and the secondary metabolites of marine actinomycetes. Meanwhile, it also can provide available potential components for the synthesis of NRPSs based on combinatorial biology.

\section{MATERIALS AND METHOD}

\section{Bioinformatics analysis of sare0718}

In order to understand the gene sare0718, the specificity-conferring code and cognate substrate of

\footnotetext{
* Corresponding author: e-mail: qichao@mail.ccnu.edu.cn

\# These authors contributed equally to this work
} 
sare0718 were analyzed by the online website “PKS/NRPS Analysis Website"' $(4,7)$.

Expression, purification and western blotting analysis of GST-Sare0718 fusion protein

As reported (4), pGEX-2T-sare0718 was transformed to E. coli BL21 competent cells and GSTSare0718 fusion protein was induced by $0.2 \mathrm{mM}$ isopropyl-b-D-thiogalactopyranoside (IPTG) at $16^{\circ} \mathrm{C}$ for $24 \mathrm{~h}$. The cells were harvested by centrifugation and re-suspended in pre-cooled lysis buffer [50mM Tris- $\mathrm{HCl}$ (pH 7.4), 0.9\% NaCl, $1 \%$ Triton $\mathrm{X}-100,1 \mathrm{mM} \mathrm{PMSF}]$, and then lysed by the highpressure homogenization. The supernatant was loaded onto a Glutathione Sepharose4B column preequilibrated with affinity buffer $[50 \mathrm{mM}$ Tris- $\mathrm{HCl}$ (pH 7.4), $0.9 \% \mathrm{NaCl}, 1 \%$ Triton $\mathrm{X}-100]$. The bound fusion protein with GST-tag was recovered by elution buffer $[50 \mathrm{mM}$ Tris- $\mathrm{HCl}(\mathrm{pH} 8.0), 20 \mathrm{mM}$ reduced glutathione]. The fusion protein was detected by western blotting by using GST tag antibody.

\section{Fluorescence quenching (FQ)}

FQ experiments were carried out at $25^{\circ} \mathrm{C}$. The assay was performed in the buffer $(50 \mathrm{mM}$ Tris- $\mathrm{HCl}$, $\mathrm{pH}$ 7.4). The working concentration of GSTSare 0718 was $1 \times 10^{-6} \mathrm{~mol} / \mathrm{L}$. And the working concentrations of 20 common amino acids were $1 \times 10^{-6}$ $\mathrm{mol} / \mathrm{L}, 2 \times 10^{-6} \mathrm{~mol} / \mathrm{L}, 4 \times 10^{-6} \mathrm{~mol} / \mathrm{L}, 6 \times 10^{-6} \mathrm{~mol} / \mathrm{L}$, $8 \times 10^{-6} \mathrm{~mol} / \mathrm{L}, 1 \times 10^{-5} \mathrm{~mol} / \mathrm{L}, 1.2 \times 10^{-5} \mathrm{~mol} / \mathrm{L}$, $1.4 \times 10^{-5} \mathrm{~mol} / \mathrm{L}, 1.6 \times 10^{-5} \mathrm{~mol} / \mathrm{L}, 1.8 \times 10^{-5} \mathrm{~mol} / \mathrm{L}$ and $2 \times 10^{-5} \mathrm{~mol} / \mathrm{L}$. The excitation and emission mono-chromators were set at $10 \mathrm{~nm}$ slit widths (8).

\section{Isothermal titration calorimetry (ITC)}

The ITC (UT 84042, TA, USA) was performed in ITC buffer (50 mM Tris-HCl, $\mathrm{pH} 7.4)$. The different ratio for gradient experiment on amino acid and fusion protein GST-Sare0718 was 2.5, 5, 10, 20 and 40, as shown in Table 1. The sample cell was added into $200 \mu \mathrm{L}$ protein solutions with a concentration 10 100 $\mu \mathrm{M}$, and the reference cell was added into a buffer with the same volume. The syringe,

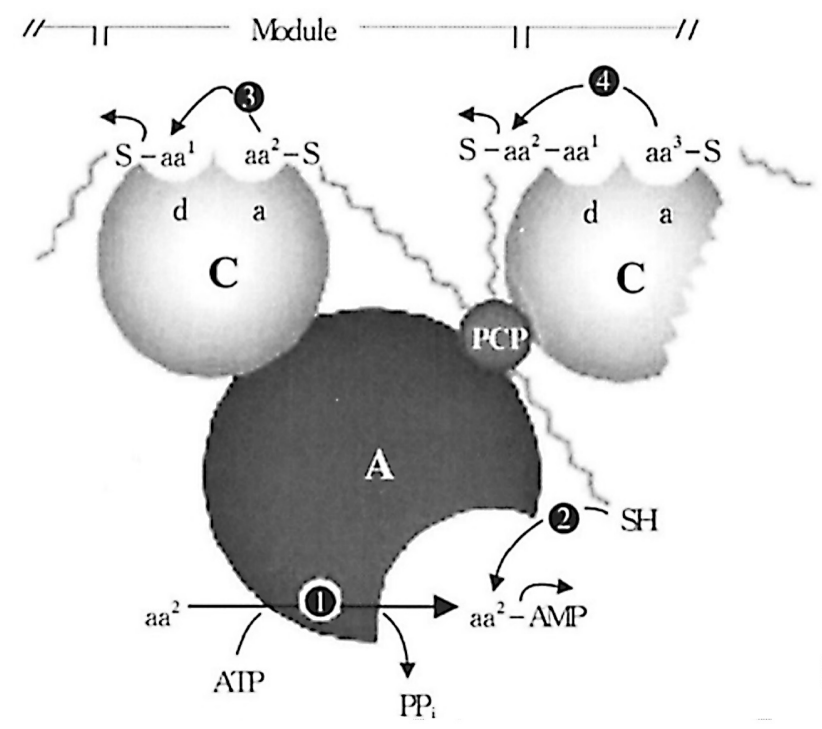

Figure 1. The composition and synthesis mechanism of one complete NRPS module (6)

Table 1. The gradient concentration of amino acids and GST-Sare0718 in ITC experiment.

\begin{tabular}{|c|c|c|}
\hline AA/GST-Sare0718 (ratio) & AA $(\mu \mathrm{mol} / \mathrm{L})$ & GST-Sare0718 $(\mu \mathrm{mol} / \mathrm{L})$ \\
\hline 2.5 & 62.5 & 25 \\
\hline 5 & $125 / 250$ & $25 / 50$ \\
\hline 10 & $250 / 500$ & $25 / 50$ \\
\hline 20 & 500 & 25 \\
\hline 40 & 2 & 50 \\
\hline
\end{tabular}


Table 2. Stern-Volmer equation data.

\begin{tabular}{|c|c|c|c|c|}
\hline Amino acid & $\mathrm{Ksv}(\mathrm{L} / \mathrm{mol})$ & $\mathrm{Kq}\left(\mathrm{L} \cdot \mathrm{mol}^{-1} \cdot \mathrm{s}^{-1}\right)$ & $\mathrm{Ka}(\mathrm{L} / \mathrm{mol})$ & $\mathrm{n}$ \\
\hline Valine (Val) & $7.34 \times 10^{4}$ & $7.34 \times 10^{12}$ & $2.656 \times 10^{5}$ & 0.2489 \\
\hline Aspartic acid (Asp) & $3.33 \times 10^{4}$ & $3.33 \times 10^{12}$ & $1.504 \times 10^{6}$ & 1.160 \\
\hline Asparagine (Asn) & $3.45 \times 10^{4}$ & $3.45 \times 10^{12}$ & $6.228 \times 10^{5}$ & 0.2776 \\
\hline Glutamine (Gln) & $4.26 \times 10^{4}$ & $4.26 \times 10^{12}$ & $1.468 \times 10^{5}$ & 0.942 \\
\hline Glutamic acid (Glu) & $4.0 \times 10^{4}$ & $4.0 \times 10^{12}$ & $6.059 \times 10^{5}$ & 0.3285 \\
\hline
\end{tabular}

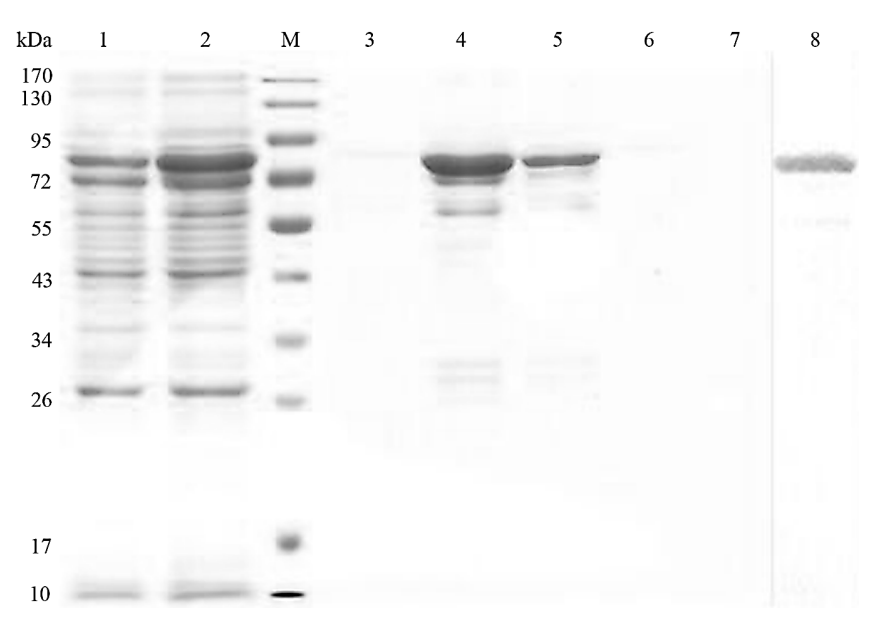

Figure 2. 10\% SDS-PAGE and western blotting analysis of recombinant GST-Sare0718 purified by Glutathione Sepharose4B affinity chromatography

used for mixing liquor, was filled with $50 \mu \mathrm{L}$ amino acid solutions with a concentration $0.5 \sim 1 \mathrm{mM}$. Injections were started after baseline stability had been achieved (8). The amino acid solutions were added sequentially in $2 \mu \mathrm{L}$ aliquots (for 25 injections) at 120 $\mathrm{s}$ intervals with being stirred at $250 \mathrm{rpm}\left(25^{\circ} \mathrm{C}\right)$.

\section{RESULTS}

\section{Bioinformatics analysis of Sare0718}

The specificity-conferring code analysis indicated that the substrate-binding pocket of Sare0718 was DMWIAAAIVK and the specific substrate was valine by the online website "PKS/NRPS Analysis Web-site", $(4,7)$.

Expression, purification and western blotting analysis of GST-Sare 0718

As shown in Figure 1, Sare0718 $(61 \mathrm{kDa})$ was expressed as a GST-tagged fusion protein GTSSare0718 $(87 \mathrm{kDa})$, consistent with the predicted molecular weight (GST-tag: 26kDa) in the $10 \%$
SDS-PAGE gel (Fig. 2: lane 3 7) (4). The presence of an N-terminal GST-tag in GST-Sare0718 protein was verified by western blotting (Fig. 2: lane 8) (4).

\section{Fluorescence quenching (FQ)}

Quenching mechanisms are usually classified as either dynamic or static. The possible quenching mechanisms can be described by the Stern-Volmer Equation: $\mathrm{F}_{0} / \mathrm{F}=1+\mathrm{K}_{\mathrm{q}} \tau_{0}[\mathrm{Q}]=1+\mathrm{K}_{\mathrm{sv}}[\mathrm{Q}](9,10)$. $\mathrm{F}_{0}$ and $\mathrm{F}$ represent the fluorescence intensities in the absence and presence of quenchers, respectively. $\mathrm{K}_{\mathrm{q}}$ is the bimolecular quenching rate constant. $\mathrm{K}_{\mathrm{sv}}$ is the dynamic quenching constant. $\tau_{0}$ represents the average lifetime of bimolecular without quenchers. Q is the concentration of quenchers $(9,10)$.

The excitation $\left(\lambda_{\mathrm{ex}}\right)$ and emission $\left(\boldsymbol{\lambda}_{\mathrm{em}}\right)$ wavelength were determined at $283 \mathrm{~nm}, 337 \mathrm{~nm}$, respectively (Fig. 3A, B). Tyrosine (Tyr) and alanine (Ala) couldn't quench fluorescence of GST-Sare0718; arginine (Arg), cysteine (Cys), glycine (Gly), histidine (His), isoleucine (Ile), serine (Ser), leucine (Leu), lysine (Lys), proline (Pro), methionine (Met), 
phenylalanine (Phe), threonine (Thr) and tryptophan (Trp) could quench limited fluorescence but no rules existed. Besides, the intrinsic fluorescence intensities of GST-Sare0718 decreased regularly and steadily due to the addition of aspartic acid (Asp), glutamine (Gln), asparagine (Asn), glutamic acid (Glu) and valine (Val). As shown in Table 2, $\mathrm{K}_{\mathrm{sv}(\mathrm{Asp})}=3.33$ $\times 10^{4} \mathrm{~L} / \mathrm{mol}, \mathrm{K}_{\mathrm{sv}(\mathrm{Gln})}=4.26 \times 10^{4} \mathrm{~L} / \mathrm{mol}, \mathrm{K}_{\mathrm{sv}(\mathrm{Val})}=$ $7.34 \times 10^{4} \mathrm{~L} / \mathrm{mol}$. Due to the endogenous fluorescent life (about $10^{-8} \mathrm{~s}$ ) of biological macromolecules (11), the parameters $\mathrm{K}_{\mathrm{q}}$ are $\mathrm{K}_{\mathrm{q}(\text { Asp })}=3.33 \times 10^{12} \mathrm{~L} \cdot \mathrm{mol}^{-1} \cdot \mathrm{s}^{-1}$, $\mathrm{K}_{\mathrm{q}(\mathrm{G} \ln )}=4.26 \times 10^{12} \mathrm{~L} \cdot \mathrm{mol}^{-1} \cdot \mathrm{s}^{-1}, \mathrm{~K}_{\mathrm{q}(\mathrm{Val})}=7.34 \times 10^{12}$ $\mathrm{L} \cdot \mathrm{mol}^{-1} \cdot \mathrm{s}^{-1}$. In general, maximal collisional quenching constant $\mathrm{Kq}$ of various kinds of quenchers to biopolymers is $2.0 \times 10^{10} \mathrm{~L} \cdot \mathrm{mol}^{-1} \cdot \mathrm{s}^{-1}(12)$. Obviously, the intrinsic fluorescence quenching process of GST-Sare0718 is assumed to be a static quenching mechanism.

The binding constants $\mathrm{K}_{\mathrm{a}}\left(\mathrm{K}_{\mathrm{a}(\mathrm{Asp})} ; \mathrm{K}_{\mathrm{a}(\mathrm{GIn})} ; \mathrm{K}_{\mathrm{a}(\mathrm{Val})}\right)$ and binding sites $\mathrm{n}$ are obtained by $\lg \left(\mathrm{F}_{0}-\mathrm{F}\right) / \mathrm{F}=\lg \mathrm{K}_{\mathrm{a}}$ $+n \lg [\mathrm{Q}](9) . \mathrm{K}_{\mathrm{a}(\mathrm{Asp})}=1.50 \times 10^{6} \mathrm{~L} / \mathrm{mol}, \mathrm{n}_{\text {(Asp) }}=1.16$. $\mathrm{K}_{\mathrm{a}(\mathrm{Gin})}=1.46 \times 10^{5} \mathrm{~L} / \mathrm{mol}, \mathrm{n}_{(\mathrm{Gln})}=0.94 . \mathrm{K}_{\mathrm{a}(\mathrm{Val})}=2.65$ $\times 10^{5} \mathrm{~L} / \mathrm{mol}, \mathrm{n}_{\text {(Val) }}=0.25$. The binding site $\mathrm{n}_{\text {(Val) }}$ is not correct. Meanwhile, only Asp and Gln kept decreasing the endogenous fluorescence of GST-Sare0718 while increasing the concentration of amino acids ( $1 \mu \mathrm{mol} / \mathrm{L}-20 \mu \mathrm{mol} / \mathrm{L}$ ) (Fig. 3C, D). And the binding constants $\mathrm{K}_{\mathrm{a}}$ are $\mathrm{K}_{\mathrm{a}(\mathrm{Asp})}=\mathrm{K}_{\mathrm{a}(\mathrm{Gln})}$. There is one binding site on GST-Sare0718. The specific substrate for GST-Sare0718 of A domain from S. arenicola CNS205 is Asp.

\section{Isothermal titration calorimetry (ITC)}

ITC is based on precise measurement of generated or absorbed heat upon the binding experiment by a successive injection (titrating) to study the molecular interactions (13). ITC can define the equilibrium constant of the reactions, which is in a range $10^{3} \sim 10^{9} \mathrm{~L} / \mathrm{mol}$.

Asp acid and Glu are screened as substrates by ITC. When the concentration of Asp or Gln was 0.5 $\mathrm{mol} / \mathrm{L}$ and the concentration of GST-Sare0718 was $0.025 \mathrm{~mol} / \mathrm{L}$, the curves as shown in Fig. 4 were obtained. The values $\mathrm{K}_{\mathrm{a}}\left(\mathrm{K}_{\mathrm{a}(\text { Asp })} ; \mathrm{K}_{\mathrm{a}(\mathrm{GIn})}\right)$ are $\mathrm{K}_{\mathrm{a}(\text { Asp })}=$ $1.22 \times 10^{5} \mathrm{~L} / \mathrm{mol}, \mathrm{K}_{\mathrm{a}(\mathrm{Gln})}=1.62 \times 10^{4} \mathrm{~L} / \mathrm{mol} . \mathrm{K}_{\mathrm{a}(\mathrm{Asp})}=$ $\mathrm{K}_{\mathrm{a}(\mathrm{Gin})}$. These results also show that Asp is the specific substrate for GST-Sare0718 of A domain from S. arenicola $\mathrm{CNS}-205$.

\section{DISCUSSIONS}

The link between substrate specificity and its spatial structure has always been noticed and researched by many scientists (14). Mohamed's group summarized and identified the sequence tags from terrestrial actinomycetes, which are constituted
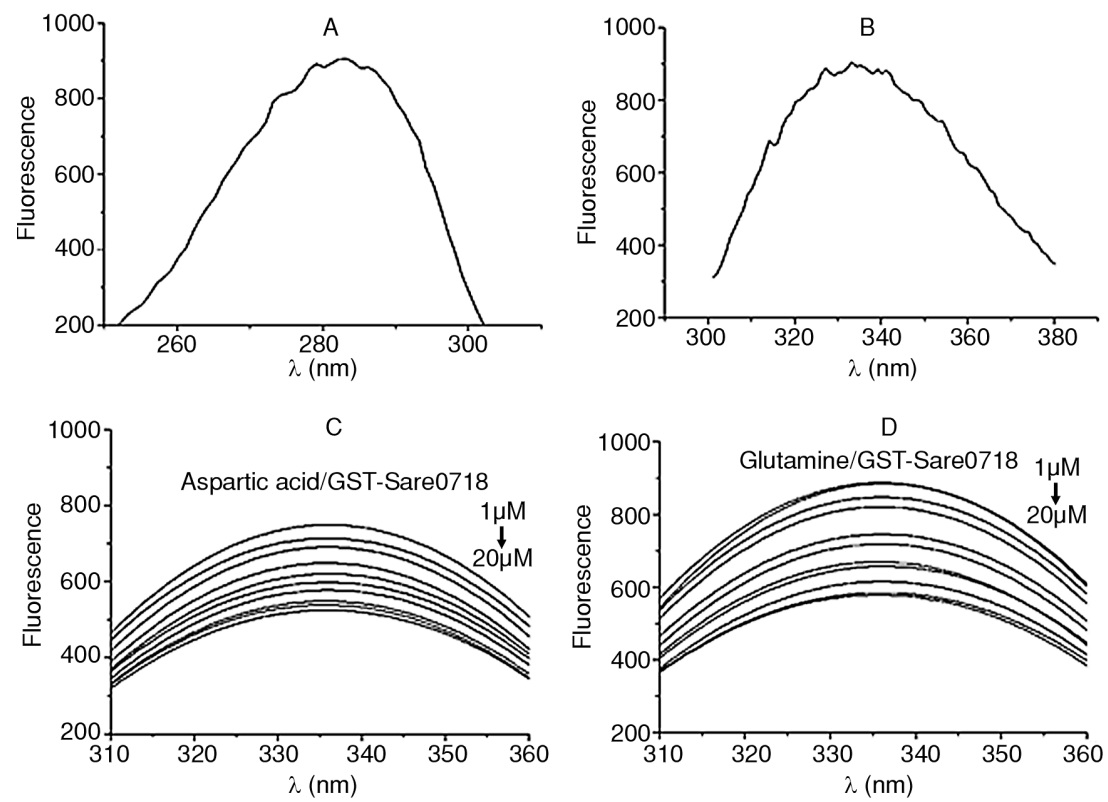

Figure 3. The spectra of GST-Sare0718 without amino acids at the excitation and emission wavelength (A, B). The spectra of GSTSare0718 with Asp (C) or Gln (D) 

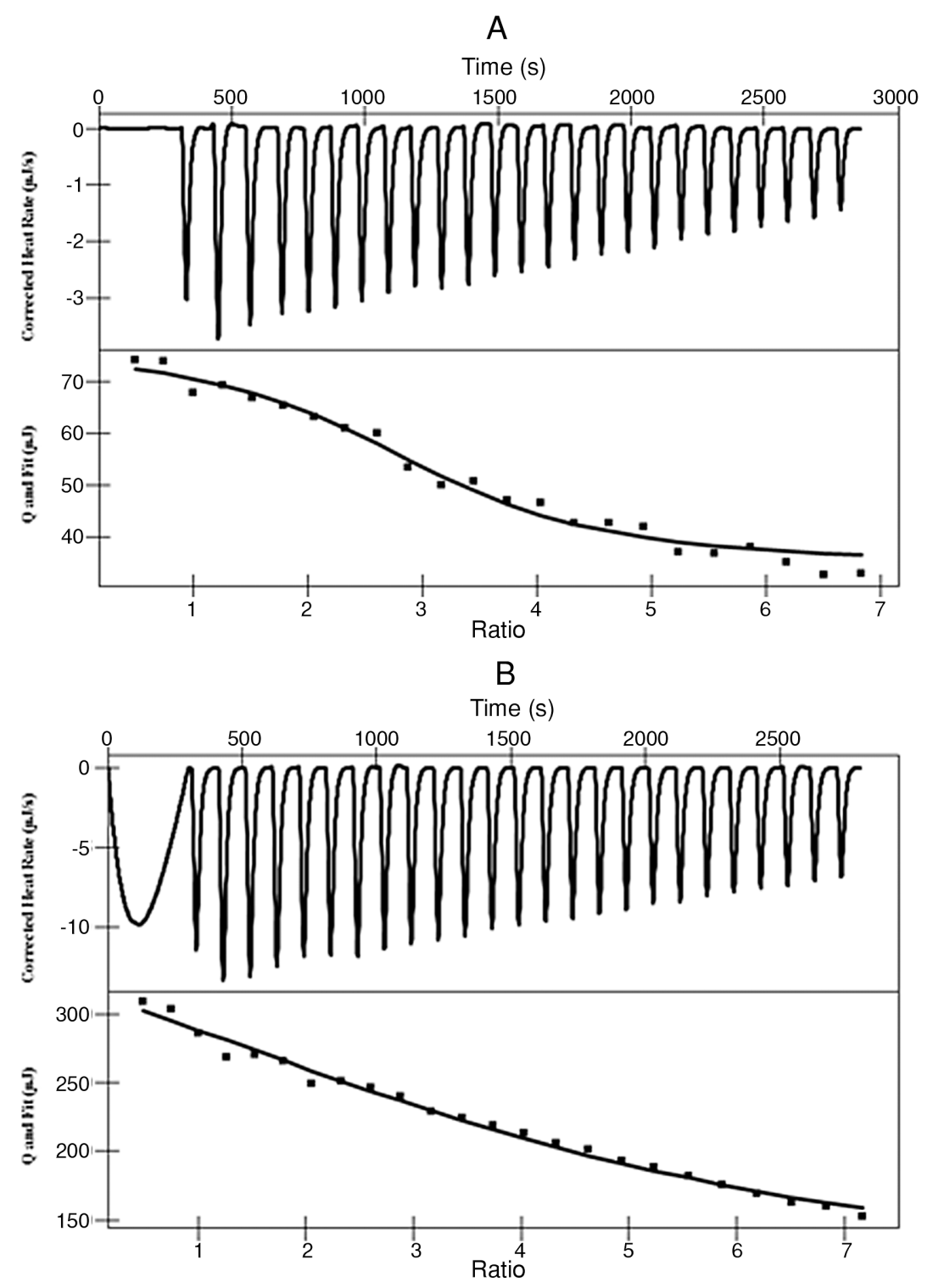

Figure 4. Calorimetric titrations for GST-Sare0718 interacting with Asp (A) and Gln (B)

by 10 amino acid residues in the sequence. The sequence tags were called as a predictive system "the specificity-conferring code" about the biosynthesis of NRPs $(15,16)$. Actually, when the predictive system was put forward, there was no any report or evidence about the real marine actinomycetes as references $(17,18)$. The predictive substrate reported in prior studies with the predictive system was not consistent with actually activated amino acid (19). For example, Andrew w. Schultz' group identified Cyclomarin (an annular anti-inflammatory, antiviral NRP, which consists of seven amino acid residues) in $S$. arenicola CNS-205. Only one predictive sub- strate is found to correspond with the experimental result. But other six retrieval results are all different with the actual results (20). Felipe's group met the same situation when they formulated the biosynthesis gene cluster and metabolic pathway of thiocoraline (an antineoplastic polypeptide) (21). These researches indicate the predictive system is not suitable for marine actinomycetes. Therefore, it is very necessary to establish a special predictive system for marine actinomycetes.

The predictive substrate is valine for GSTSare0718. But in the research, Asp is conformed actually as the specific substrate. It may be related to 
the significant difference in the physiology and phylogenetic development between marine and terrestri$\mathrm{al}$ actinomycetes. According to the data, $\mathrm{K}_{\mathrm{a}}$ and $\mathrm{K}_{\mathrm{a}}$ ' calculated by FQ and ITC are not completely the same. But the screened substrates are the same, and the order of binding constant between them is the same.

The experimental results can provide the basis for a new predictive system. In summary, our study not only enriches the substrate specificity of A domain from $S$. arenicola CNS-205, but also set up a foundation for researching codes. Meanwhile, it also can provide available potential components for the synthesis of NRPSs based on combinatorial biology.

\section{CONCLUSION}

Actinomycetes are very important in the development of natural pharmaceutical products, such as polyketides (PKs) and NRPs. Besides, adenylation domain (A domain) is a model of non-ribosomal peptide synthetases (NRPs), responsible for binding and activating the substrates-amino acids. After screening the substrates of GST-Sare0718, it showed Asp is the specific one. The data indicates that the prediction system, "the specificity-conferring code", is not suitable for marine actinomycetes.

\section{Conflict of interest}

The authors confirm that this article content has no conflict of interest.

\section{Acknowledgements}

S. arenicola CNS-205 was presented by Hai Deng, who was in the University of Aberdeen. The study was supported by the national natural science foundation of China (No. 20772040, 31672284, 31272645 ) and the ministry of education of the central university autonomous project (No. CCNU14F01006).

\section{REFERENCES}

1. Ng Y.K., Hewavitharana A.K., Webb R., Shaw P.N., Fuerst J.A.: Appl. Microbiol. Biotechnol. 97, 3097 (2013).

2. Subramani R., Aalbersberg W.: Microbiol. Res. 167, 571 (2012).

3. Zotchev S.B.: J. Biotechnol. 158, 168 (2012).

4. Xia S.S., Ma Y.L., Zhang W., Yang Y., Wu S. et al.: PlosS One 7, 1 (2012).

5. Udwary D.W., Zeigler L., Asolkar R.N., Singan V., Lapidus A. et al.: Proc. Natl. Acad. Sci. U.S.A. 104, 10376 (2007).

6. McQuade T.J., Shallop A.D., Sheoran A., Delproposto J.E., Tsodikov O.V., GarneauTsodikova S.: Anal. Biochem. 386, 244 (2009).

7. Bachmann B.O., Ravel J.: Methods. Enzymol. 458, 181 (2009).

8. Lei M., Zhang H., Zhao Z.J., Liu K., Hu Y.X. et al.: Acta. Pol. Pharm. (accepted).

9. Jiang X.Y., Li W.X., Cao H.: J. Solution. Chem. 37, 1609 (2008).

10. Lakowicz J.R., Weber G.: Biochem. 12, 4167 (1973).

11. Pannipara M., Asiri A.M., Alamry K.A., Arshad M.N., El-Daly S.A.: J. Fluoresc. 24, 1629 (2004).

12. Kathiravan A., Chandramohan M., Renganathan R., Sekar S.: J. Mol. Struct. 919, 210 (2009).

13. Draczkowski P., Matosiuk D., Jozwiak K.: J. Pharm. Biomed. Anal. 87, 313 (2014).

14. Conti E., Stachelhaus T., Marahiel M.A., Brick P.: EMBO. J. 16, 4174 (1997).

15. Stachelhaus T., Mootz H.D., Marahiel M.A.: Chem. Biol. 6, 493 (1999).

16. Challis G.L., Ravel J., Townsend C.A.: Chem. Biol. 7, 211 (2000).

17. Maldonado L.A., Fenical W., Jensen P.R., Kauffman C.A., Mincer T.J. et al.: Int. J. Syst. Evol. Microbiol. 55, 1759 (2005).

18. Penn K., Jenkins C., Nett M., Udwary D.W., Gontang E.A. et al.: ISME. J. 3, 1193 (2009).

19. Li J., Jensen S.E.: Chem. Biol. 15, 118 (2008).

20. Schultz A.W., Oh D.C., Carney J.R., Williamson R.T., Udwary D.W. et al.: J. Am. Chem. Soc. 130, 4507 (2008).

21. Lombó F., Velasco A., Castro A., de la Calle F., Brańa A.F. et al.: ChembioChem. 7, 366 (2006).

Received: 15. 12.2017 